\title{
Genetic Analysis of Barnyard Millet (Echino chloafrumentacea (Roxb.) Link) Germplasm Collected from Uttarakhand Hills for Morphological Traits
}

\author{
Ranjana, A. S. Jeena*, Ankit Kumar and Rohit \\ Department of Genetics and Plant Breeding, G. B. Pant University of Agriculture \\ and Technology, Pantnagar, India, \\ *Corresponding author
}

\section{A B S T R A C T}

\section{Keywords}

germplasm morphological culm branching

\section{Article Info}

Accepted:

05 February 2020

Available Online:

10 March 2020
The present investigation was conducted with 87 germplasm accessions of barnyard millet along with two checks (VL181 and PRJ-1). The data was recorded for 13 morphological and 10 yield attributing traits. All accessions were observed to have erect growth habit and one-sided spikelet arrangement with complete absence of lower raceme branching. Majority of germplasm entries exhibit presence of culm branching and concave grain shape. Most of the accessions exhibit pyramidical inflorescence of greencolour and compact panicle having grey or light grey grain, thick lower raceme and absence of lodging. Intermediate, phenotype was exhibited by germplasms with respect to presence or absence of pigmentation at internodes and leaf sheath, and straight or curved lower raceme shape. A wide range of mean values were exhibited by the accessions for all the characters.High PCV and GCV was recorded for lower raceme length and peduncle length along with high heritability and high genetic advance as per cent of mean, indicating predominance of additive effects in expression of these traits and high efficiency of phenotypic selection for these characters.

\section{Introduction}

Millets are the oldest food grains of Poaceae family and are originated in Eastern Asian regions. The word 'millet' gets its origin from the French word "mille" i.e. thousand (Handful of millet containing up to 1000 grains). Millets belongs to the group of small-seeded species of cereal crops or grains which are annual plants. They are major sources of food and feed in developing countries, especially in arid and semi-arid tropical regions of Africa as well as Asia.

Across the globe, minor millets such as finger millet (Eleusine coracana), kodo millet (Paspalums scorbiculatum), small millet (Panicum sumatrense), foxtail millet (Setaria italica), proso millet (Panicum miliaceum) and barnyard millet (Echinochloa 
frumentacea) are extensively cultivated. Millets have excellent farming features and can grow under extreme environmental conditions where other crops do not grow well or yield well.

Owing to their short growth period these plants are also cultivated as a mixed crop with other cereal crops. Millets are rich in nutrients and also considered as a healthy food because of its gluten free nature. Because of its abundance in nutrients such as starch, protein, fibre, and well-balanced amino acid profile, it will continue to do so in the future also (Etherton et al., 2002 and Mattila et al., 2005).

During the year 2017-18, Nutri Cereals recorded total area, production and productivity of 24.21 million hectares, 46.99 million tonnes and $1941 \mathrm{~kg} / \mathrm{ha}$ (DES, 2018).

Barnyard millet (Echinochloa spp.) is an essential crop for farmers in the Asian countries for their livelihood because of its drought tolerance, rapid maturation, and superior nutritional qualities. There are total 20 species present in Genus Echinochloa. In India, China, Japan, Pakistan, Africa and Nepal; 2 major cultivated species Echinochloa frumentacea and E. utilis, both cultivated as minor cereals. Barnyard millet is also known as Billion-dollar grass.

It belongs to Subfamily Panicoideae. It is a Hexaploid crop having Chromosome number $2 \mathrm{n}=6 \mathrm{x}=36$ (Wallace et al., 2015, Tadele, 2016).This crop is used as substitute for milled rice (Oryza sativa L.) when paddy fails to grow, it is highly nutritious, rich in proteins, lipids, and vitamins B1 and B2 compared to other cereals such as rice and wheat grains.

Japanese barnyard millet (E. utilis) grains were used as a safe food for allergic disease patients including atopic dermatitis (Kim et al., 2011). Barnyard millet is extensively grown in India in the central part where it is known as sawa, shama, samu, shamula, kudiraivali and sanva. The production is limited predominantly to the tribal regions of Orissa, Maharashtra, Madhya Pradesh, Tamil Nadu, Bihar, Punjab, Gujrat and Uttarakhand hills. It is one of Uttarakhand's most common minor cereal kharif crop and is grown in rainfed conditions in hills up to 2,000 $\mathrm{m}$ high.

It is often cultivated as a crop that borders other crops (Kumar et al., 2000). In Uttarakhand, during 2016-17, In Garhwal region area under barnyard millet production was 37758 hectares with production $55337(\mathrm{mt})$ and in kumaon region area was 17679 hectare and production $23140 \mathrm{mt}$. In Uttarakhand, total area under barnyard millet production was 55437 hectare and production $78477 \mathrm{mt}($ Anonymous, 2020).

Agricultural land is decreasing day by day and irrigated lands are utilised to its full extent so there is a need to concentrate on dry lands to combat the nutritional demand and to further increase the yield of food grains. Barnyard millet has many economic and nutritional properties but much overlooked crop at both national and international levels. Estimation and use of genetic variability are very important in plant breeding. For effective management and use of germplasm one should have the knowledge about diversity pattern and genetic composition of gene pool.

New sources of beneficial traits need to be discovered so that a mixture of alleles creates progenies with superior performance. Selection and improvement of any crop depends on genetic variability. Variability is eroding very fast due to destruction of natural habitats wild cultivated species are being demolished and traditional cultivars is being replaced by modern cultivars. Plant genetic resources, provides the natural available 
variability for breeding new varieties of crops. Therefore, characterization of germplasm is an important step towards the utilization of genetic resources. The present investigation was conducted for the exploring variability among the Barnyard millet germplasm genotypes collected from the Uttarakhand hills and studying the genetic parameters of these populations.

\section{Materials and Methods}

The present investigation was conducted during 2016 and 2017 kharif season at P.C.P.G.R. (Pantnagar Centre for Plant Genetic Resource) research block, G.B.P.U.A. \& T. Pantnagar, Distt. Udham Singh Nagar, Uttarakhand. The trails included87accessions of Barnyard millets germplasm along with 2 standard checks namely VL181 and PRJ-1.The experiment was laid out in RBD (randomized block design) with three replications, having row length of $3 \mathrm{~m}$, row to row distance of $30 \mathrm{~cm}$ and plant to plant distance was of $10 \mathrm{~cm}$. Observations were recorded on 23 morphological parameters which included discrete as well as continuous measurements.

Data was recorded on randomly selected ten plants per plot at different stages of development and at the time of harvesting. The traits studied were plant growth habit, Basal tiller number, Pigmentation at internodes and leaf sheath, Flag leaf length (cm),Flag leaf width (cm),Peduncle length (cm), Inflorescence shape, Inflorescence colour Panicle compactness, Spikelet arrangement on rachis, Lower racemes Shape, Lower racemes Thickness, Lower racemes branching, Culm branching, Lower raceme length $(\mathrm{cm})$,Panicle length $(\mathrm{cm})$,Plant height, Lodging, Grain colour, Grain shape,1000 seed weight, Grain yield per plot and Biological yield. The data was analyzed in RBD to test the significance of differences between the genotypes for various characters and the steps involved were as described by Panse and Sukhatme (1969).Pooled analysis of variance was drawn for 2016 and 2017 over the years following homogeneity of variance through $\mathrm{F}$ test. Genotypic and phenotypic coefficients of variance were computed as per as method suggested by Burton (1952). Heritability in a broad sense $\left(\mathrm{H}_{\mathrm{b}}\right)$ and Genetic advance were estimated as per (Allard, 1960).

\section{Results and Discussion}

\section{Characterization of visually assessed morphological traits}

Visual assessment of 87 finger millet germplasm accessions was done for all the 13 qualitative traits as furnished in Table 1. For the plant growth habit, all the 87 accessions were observed to be erect type. Amongst all the genotype, 46 showed pigmentation at internodes and leaf sheath. For inflorescence shape, genotypes were classified into three groups viz., cylindrical (33), pyramidical (41) and globose-elliptical (13). The green inflorescence color was dominant and observed in 57 accessions whereas rest exhibited light purple (12) and dark purple (18).

The character panicle compactness was categorized into three groups, highest being compact type (43) followed by intermediate type (34) and open type (10). The spikelet arrangement on the rachis was observed to be one sided for all the accessions. For lower raceme shape, straight type was observed in 49 accessions and rest 38 showed curved type. The lower raceme thickness was observed to be of thick type in 60 accessions while the rest of the 27 accessions showed slender type. Lower raceme branching was absent in all the accessions. 81 accessions showed presence of culm branching while the remaining six accessions had no culm branching. The 
lodging trait was absent in most (58) of the accessions whereas the trait was present for 29 accessions. The grain color was grouped into three classes, light grey color shown by 39 followed by grey color by 38 and straw white by 10 germplasms. Seventy-seven entries exhibited concave type of grain shape whereas the rest 10 showed oval type.

\section{Mean performances of barnyard millet germplasm}

A wide range of mean values were exhibited by the accessions for quantitative morphological traits viz., basal tiller number, flag leaf blade length, flag leaf blade width, peduncle length, lower raceme length, panicle length, 1000 seed weight, plant height, yield/ plot and biological yield / plot.

In Table 2, the mean performances of all the accessions for different characters is enlisted. General mean for basal tiller number was found to be 2.195.The accession GP-2011436 had the lowest whereas PGR-SA-13-07 had the highest number of basal tiller number. Overall three accessions PGR-SA-13-07 (2.63), GP-2011-387 (2.62), SANWA 787 (2.62) were found to be significantly superior over the check PRJ-1 (2.61). The general mean for flag leaf length was found 36.182 $\mathrm{cm}$, it ranged from $28.66 \mathrm{~cm}-45.05 \mathrm{~cm}$ GP2011-527 had the lowest finger number, while GP-2011-567 had the highest.

Thirteen accessions were found significantly superior over the check VL181out of which best five accessions were GP-2011-567 (45.05), SANWA 7902 (43.94), GP-2011-565 (42.63), PGR-SA-25-07 (42.22) and SANWA 7893 (41.90). Flag leaf blade width varied from 2.09 to $4.14 \mathrm{~cm}$ with general mean of $2.72 \mathrm{~cm}$. SANWA 7886 exhibited maximum blade width. Forty accessions appeared as significantly superior over the check PRJ-1 out of which five best accessions were
SANWA $7886 \quad$ (4.14), LD349 (3.40), SANWA 7893 (3.29), SANWA 7895(3.20) and GP-2011-568 (3.19). Forty-two accessions were found significantly superior over the check PRJ-1 for peduncle length out of these first five rankings accessions were SANWA 7879 (26.22), SANWA 7650 (26.00), SANWA 7875 (25.90), SANWA 7874 (25.90) and SANWA 7883 (24.87). The values for lower raceme length was found to vary from 2.19-6.09 $\mathrm{cm}$ with general mean of $3.25 \mathrm{~cm}$. SANWA 7895recorded the highest raceme length whereas SANWA 7881 that of lowest raceme length.

Overall 55 accessions exhibited significant superiority over the check PRJ-1. The five best accessions were SANWA 7895 (6.09), SANWA 7886 (5.79), GP-2011-129 (5.45), SANWA 7875 (5.43) and PGR-SA-11-07 (5.40). For panicle length general mean came out $25.099 \mathrm{~cm}$ with highest value for SANWA 7901 (33.64) and smallest value for PGR-SA-18-07 (18.45). Forty-two accessions were found to be significantly superior over the check VL181.

The best of the five accessions were SANWA 7901 (33.64), SANWA 7887 (31.72), SANWA 7902 (31.21), SANWA 7879 (30.36) and SANWA 7615 (29.99). General mean for 1000 seed weight was $3.319 \mathrm{~g}$. A total of twelve accessions were found significantly superior than the check PRJ-1 of which the best five performers were PGR-SA16-07 (3.74), GP-2011-11 (3.70), PGR-SA12-07 (3.67), SANWA 7908 (3.62) and GP2011-393 (3.62).

General mean for plant height was recorded as $206.213 \mathrm{~cm}$. With SANWA 8219 (177.56) having the lowest value and SANWA 7892 (227.78) with the highest. A total of 69 accessions were noted to be significantly superior over the check VL181.The first five ranking accessions were SANWA 7892 
(227.78), SANWA 7875 (227.78), PGR-SA25-07 (226.00), GP-2011-368 (224.22) and PGR-SA-4-07 (223.78).

For Yield/ plot, a total of forty-eight accessions were found to be numerically superior, with a range varying from 170.35253.81g. Among the accessions GP-2011-387 had the highest yield/ plot. Five best entries viz., GP-2011-387 (253.81), SANWA 7874(251.81), GP-2011-422 (250.70), PGRSA-13-07(249.58) and GP-2011-565 (249.15) were numerically superior over PRJ-1.

The general mean for this character was found 217.442 g. Biological yield per plot exhibited general mean of $813.114 \mathrm{~g}$ and varied from 648.85 to 962.84 g. GP-2011-387 reflected the highest biological yield. In all total four accessions were found to be significantly superior over check PRJ-1. The four best accessions were GP-2011-387 (962.84), SANWA 7889 (959.64), SANWA7874 (954.25) and GP-2011-565 (949.84).

\section{Genotypic and phenotypic coefficients of variation}

The estimate of genotypic (GCV) and phenotypic (PCV) coefficients of variation are represented in Table 3. It is apparent from the table that the phenotypic coefficient of variations was higher than genotypic coefficient of variations. For all the characters studied, GCV and PCV values were categorized as low, moderate and high as indicated below following Sivasubramanian and Menon (1973).

0-10\%: Low, 10-20\%: Moderate, $20 \%$ and above: High

Highest genotypic coefficient of variation (GCV) was observed for lower raceme length $(25.95 \%)$ followed by peduncle length $(22.25 \%)$. Further moderate GCV \% was recorded for flag leaf blade width as $10.32 \%$ while plant height, yield/plot, 1000-seed weight, basal tiller number, biological yield per plot, flag leaf blade length panicle length showed the lowest GCV as 4.33, 5.27, 7.56, $7.75,7.81,8.83$ and 9.56 respectively.

Phenotypic coefficient of variations (PCV) was estimated to be highest for lower raceme length $(26.37 \%)$ followed by peduncle length which was recorded as $22.76 \%$. Moderate PCV was noticed for flag leaf blade width (11.79\%), panicle length (10.37\%), basal tiller number $(10.28 \%)$ and flag leaf blade length (10.21\%). Low PCV was exhibited by biological yield/plot (9.56), yield/plot (8.24), 1000-seed weight (7.66) and plant height (5.19).

High PCV and GCV was recorded for characters lower raceme length and peduncle length along with high heritability and high genetic advance as per cent of mean, which indicated predominance of additive gene action in expression of these traits and high efficiency of phenotypic selection for these characters.

\section{Heritability and genetic advance}

The estimates of heritability and genetic advance are also enlisted in Table 3. The heritability was categorized as low, moderate and high category as given by Robinson et al., (1949) and described below.

0-30\%: Low 30-60\%: Moderate $60 \%$ and above: High.

1000 seed weight (97.33\%), lower raceme length $(96.90 \%)$ and peduncle length $(95.56 \%)$ recorded highest heritability values. High heritability values were also recorded for panicle length (85.02\%),flag leaf blade width (76.63\%), flag leaf blade length $(74.86 \%)$ and plant height $(69.55 \%)$ and 
biological yield / plot (66\%).They were followed by basal tiller number $(56.92 \%)$ and yield/ plot (40.97\%) which showed moderate heritability. Genetic advance as per cent mean was also categorized as given by Johnson et al., (1955) in low, moderate and high category as $0-10 \%$ : Low $10-20 \%$ :

Moderate 20\% and above: High

Table.1 Distribution of Barnyard millet accessions for different qualitative characters

\begin{tabular}{|c|c|c|c|}
\hline S. No & Character & Class & Accessions \\
\hline \multirow[t]{3}{*}{1.} & \multirow[t]{3}{*}{ Plant Growth Habit } & Erect & 87 \\
\hline & & Decumbent & 0 \\
\hline & & Prostrate & 0 \\
\hline \multirow[t]{2}{*}{2.} & \multirow{2}{*}{$\begin{array}{c}\text { Pigmentation at internodes and } \\
\text { leaf sheath }\end{array}$} & Absent & 41 \\
\hline & & Present & 46 \\
\hline \multirow[t]{3}{*}{3.} & \multirow[t]{3}{*}{ Inflorescence shape } & Cylindrical & 33 \\
\hline & & Pyramidical & 41 \\
\hline & & Globose- elliptical & 13 \\
\hline \multirow[t]{3}{*}{4.} & \multirow[t]{3}{*}{ Inflorescence Color } & Green & 57 \\
\hline & & Light Purple & 12 \\
\hline & & Dark Purple & 18 \\
\hline \multirow[t]{3}{*}{5.} & \multirow[t]{3}{*}{ Panicle compactness } & Open & 10 \\
\hline & & Intermediate & 34 \\
\hline & & Compact & 43 \\
\hline \multirow[t]{2}{*}{6.} & \multirow{2}{*}{$\begin{array}{l}\text { Spikelet Arrangement on the } \\
\text { rachis }\end{array}$} & One side & 87 \\
\hline & & Around & 0 \\
\hline \multirow[t]{2}{*}{7.} & \multirow[t]{2}{*}{ Lower Raceme Shape } & Straight & 49 \\
\hline & & Curved & 38 \\
\hline \multirow[t]{2}{*}{8.} & \multirow[t]{2}{*}{ Lower Raceme Thickness } & Slender & 27 \\
\hline & & Thick & 60 \\
\hline \multirow[t]{2}{*}{9.} & \multirow[t]{2}{*}{ Lower raceme branching } & Absent & 87 \\
\hline & & Present & 0 \\
\hline \multirow[t]{2}{*}{10.} & \multirow[t]{2}{*}{ Culm branching } & Absent & 6 \\
\hline & & Present & 81 \\
\hline \multirow[t]{2}{*}{11.} & \multirow[t]{2}{*}{ Lodging } & Absent & 58 \\
\hline & & Present & 29 \\
\hline \multirow[t]{3}{*}{12.} & \multirow[t]{3}{*}{ Grain color } & Straw white & 10 \\
\hline & & Light grey & 39 \\
\hline & & Grey & 38 \\
\hline \multirow[t]{2}{*}{13.} & \multirow[t]{2}{*}{ Grain shape } & Concave & 77 \\
\hline & & Oval & 10 \\
\hline
\end{tabular}


Table.2 General mean, range of variability and superior accessions of finger millet for yield and its components

\begin{tabular}{|c|c|c|c|c|c|}
\hline S. No. & Name of Character & $\begin{array}{l}\text { General } \\
\text { mean }\end{array}$ & Range & $\begin{array}{l}\text { Significantly } \\
\text { superior } \\
\text { accessions }\end{array}$ & Best performing germplasm \\
\hline 1 & Basal Tiller no. & 2.195 & $1.68-2.63$ & 3 & PGR-SA-13-07(2.63), GP-2011-387(2.62) and SANWA 7874(2.62) \\
\hline 2 & $\begin{array}{l}\text { Flag Leaf Blade } \\
\text { Length }(\mathrm{cm})\end{array}$ & 36.182 & $28.66-45.05$ & 13 & $\begin{array}{l}\text { GP-2011-567(45.05), SANWA 7902(43.94), GP-2011-565(42.63), PGR- } \\
\text { SA-25-07(42.22) and SANWA 7893(41.90) }\end{array}$ \\
\hline 3 & $\begin{array}{l}\text { Flag Leaf Blade } \\
\text { width }(\mathrm{cm})\end{array}$ & 2.724 & $2.09-4.14$ & 40 & $\begin{array}{l}\text { SANWA 7886(4.14), LD 349(3.40), SANWA 7893(3.29) SANWA } \\
7895(3.20) \text { and GP-2011-568(3.19) }\end{array}$ \\
\hline 4 & Peduncle Length $(\mathrm{cm})$ & 16.875 & $11.15-26.22$ & 42 & $\begin{array}{l}\text { SANWA } 7879(26.22) \text {, SANWA 7650(26.00), SANWA 7875(25.90), } \\
\text { SANWA7874 (25.90) and SANWA 7883(24.87) }\end{array}$ \\
\hline 5 & $\begin{array}{l}\text { Lower Raceme } \\
\text { Length }(\mathrm{cm})\end{array}$ & 3.255 & $2.19-6.09$ & 55 & $\begin{array}{l}\text { SANWA7895(6.09), SANWA 7886(5.79), GP-2011-129(5.45), SANWA } \\
\text { 7875(5.43) and PGR-SA-11-07(5.40) }\end{array}$ \\
\hline 6 & Panicle Length $(\mathrm{cm})$ & 25.099 & $18.45-33.64$ & 42 & $\begin{array}{llll}\text { SANWA7901(33.64), SANWA7885(31.72), } & \text { SANWA } & \text { 7902(31.21), } \\
\text { SANWA7879(30.36) and SANWA 7615(29.99) } & & \end{array}$ \\
\hline 7 & 1000 Seed weight $(\mathrm{g})$ & 3.319 & $2.03-3.74$ & 12 & $\begin{array}{l}\text { PGR-SA-16-07(3.74), GP-2011-11(3.70), PGR-SA-12-07 (3.67), SANWA } \\
7908 \text { (3.62) and GP-2011-393 (3.62) }\end{array}$ \\
\hline 8 & Plant Height $(\mathrm{cm})$ & 206.213 & $177.56-227.78$ & 69 & $\begin{array}{l}\text { SANWA7892(227.78), SANWA7875(227.78), PGR-SA-25-07(226.00), } \\
\text { GP-2011-368(224.22) and PGR-SA-4-07(223.78) }\end{array}$ \\
\hline 9 & Yield $(\mathrm{g}) /$ plot & 217.442 & $170.35-253.81$ & 5 & $\begin{array}{l}\text { GP-2011-387(253.81), SANWA 7874(251.81), GP-2011-422(250.70), } \\
\text { PGR-SA-13-07(249.58) and GP-2011-565(249.15) }\end{array}$ \\
\hline 10 & $\begin{array}{l}\text { Biological } \\
\text { yield(g)/plot }\end{array}$ & 813.114 & $648.85-962.84$ & 4 & GP-2011-387(962.84) \\
\hline
\end{tabular}


Table.3 Genetic parameters for different morphological traits in barnyard millet

\begin{tabular}{|c|c|c|c|c|c|}
\hline $\begin{array}{c}\text { Genetic } \\
\text { Parameters }\end{array}$ & $\begin{array}{c}\text { Basal Tiller } \\
\text { number }\end{array}$ & $\begin{array}{l}\text { Flag leaf blade } \\
\text { length }\end{array}$ & $\begin{array}{l}\text { Flag leaf blade } \\
\text { width }\end{array}$ & $\begin{array}{l}\text { Peduncle } \\
\text { length }\end{array}$ & $\begin{array}{l}\text { Lower } \\
\text { raceme } \\
\text { Length }\end{array}$ \\
\hline GCV (\%) & 7.75 & 8.83 & 10.32 & 22.25 & 25.95 \\
\hline PCV (\%) & 10.28 & 10.21 & 11.79 & 22.76 & 26.37 \\
\hline $\begin{array}{c}\mathbf{h}^{2}(\text { Broad Sense }) \\
(\%)\end{array}$ & 57 & 75 & 77 & 96 & 97 \\
\hline $\begin{array}{l}\text { Genetic } \\
\text { Advance }\end{array}$ & 0.26 & 5.70 & 0.51 & 7.56 & 1.71 \\
\hline GAM (\%) & 12.05 & 15.74 & 18.61 & 44.80 & 52.63 \\
\hline $\begin{array}{c}\text { Genetic } \\
\text { Parameters }\end{array}$ & Panicle length & $\begin{array}{c}1000 \text { seed } \\
\text { weight }\end{array}$ & Plant Height & Yield/plot & $\begin{array}{l}\text { Biological } \\
\text { yield/Plot }\end{array}$ \\
\hline GCV (\%) & 9.56 & 7.56 & 4.33 & 5.27 & 7.81 \\
\hline $\operatorname{PCV}(\%)$ & 10.37 & 7.66 & 5.19 & 8.24 & 9.56 \\
\hline $\begin{array}{c}\mathbf{h}^{2}(\text { Broad Sense }) \\
(\%)\end{array}$ & 85 & 97 & 70 & 41 & 66 \\
\hline $\begin{array}{l}\text { Genetic } \\
\text { Advance }\end{array}$ & 4.56 & 0.51 & 15.34 & 15.12 & 106.9 \\
\hline GAM (\%) & 18.17 & 15.36 & 7.44 & 6.95 & 13.15 \\
\hline
\end{tabular}

The estimates of genetic advance expressed as per cent of mean were high for lower raceme length $(52.63 \%)$ and peduncle length (44.80\%).Flag leaf blade width $(18.61 \%)$, panicle length $(18.17 \%)$, flag leaf blade length (15.74\%), 1000 seed weight (15.36), biological yield/plot(13.15\%) and basal tiller number $(12.05 \%)$ exhibited moderate genetic advance as percent of mean whereas plant height $(7.44 \%)$ and yield/plot $(6.95 \%)$ showed the lowest GA as \% of mean values.

Lower raceme length and peduncle length expressed high heritability which was accompanied by higher values for genetic advance as percent of mean, thereby indicating the preponderance of additive genetic effects in expression of these characters. Therefore, phenotypic selection for these characters in segregating generations would likely to be more effective. In case of traits such as 1000 grain weight, panicle length, flag leaf blade width, flag leaf blade length and biological yield / plot where high heritability was coupled with moderate genetic advance as percent of mean indicating that gene governing this character is under the influence of dominant effect.

For yield/ plot both heritability and genetic advance had low values that indicates high influence of environmental factor that means phenotypic selection is ineffective for this character. Mohan et al., (2019) also reported the similar results of higher heritability in broad sense for panicle length and tillers per plant and high heritability coupled with high genetic advance as percent of mean was observed in tillers per plant followed by test weight $(\mathrm{g})$, panicle length $(\mathrm{cm})$, fodder yield (g) and plant height $(\mathrm{cm})$ in foxtail millet. Ayesha et al., (2019) also found high 
heritability with high genetic advance for number of tillers per plant, inflorescence length, flag leaf blade width, single plant yield and yield per plot observed that GCV were lesser than the corresponding PCV. Singamsetti et al., (2018) also reported that the grain yield and its contributing characteristics such as plant height, panicle length showed high genetic advance as per cent of mean with high estimates of heritability.

\section{Acknowledgement}

Authors are thankful to Head, Genetics and Plant Breeding, Director Research and Nodal Officer, PCPGR, G B Pant University of Agriculture and Technology, Pantnagar for providing research facilities during course of the present study. The financial help provided by Department of Science and Technology (DST), New Delhi through the project under TIME-LEARN programme of SEED division is hereby duly acknowledged.

\section{References}

Allard, R.W. 1960. Principle of plant breeding. John Wiley and Sons Co. New York. pp. 485.

Anonymous, 2020. Directorate of Agriculture, Uttarakhand Dehradun.

Ayesha, M., Babu, D. R., Babu, J. D. P. and Rao, V. S. 2019. Genetic Parameters for Grain Yield and Nutritional Quality Traits in Foxtail Millet [Setaria italica (L). Beauv.]. Int. J. Curr. Microbiol. App. Sci, 8(2): 4-9.

Burton, G.W. and De Vane, E.H. 1953. Estimating heritability in tall Festuca (Festuca arundinaceae) from replicated clonal material. Agron. J. 45: $478-$ 481.

DES. (2018). Area, production and productivity of crops. Agricultural statistics at a glance 2018, pp. 80-81,
Directorate of Economics and Statistics,

Department of Agriculture and Cooperation, Government of India.

Etherton, P. M., Harris, W. S. and Appel, L. J. 2002. Fish consumption, fish oil, omega-3 fatty acids and cardiovascular disease. circulation, 106(21): 27472757.

Johnson, H. W., Robinson, H. F. and Comstock, R. E. 1955. Estimates of genetic and environmental variability in soybeans. Agronomy Journal, 47(7): 314-318.

Kim, J. Y., Jang, K. C., Park, B. R., Han, S. I., Choi, K. J., Kim, S. Y., Oh, H. H., Ra, J. E., Ha, T. J., Lee, J. H., Hwang, J., Kang, H. W. and Seo, W. D. 2011. Physicochemical and antioxidative properties of selected Barnyard millet (Echinochloa utilis) species in Korea. Food Sci. Biotechnol., 20(2): 461-469.

Kumar, P., Jyothi Lakshmi, N., Dube, S. D and Mani, V. P. 2000. Genotypic difference in photosynthesis and its associated parameters in relation to yield among barnyard millet (Echinochloa frumentacea) genotypes under rainfed condition in hills. Indian Journal of Agricultural Science, 70 (6): 374-377.

Mattila, P., Pihlava, J. M. and Hellström, J. 2005. Contents of phenolic acids, alkyland alkenylresorcinolsand avenanthramides in commercial grain products. Journal of Agricultural and Food Chemistry, 53(21): 8290-8295.

Mohan, N., Ravishankar, C. R., Lohithaswa, H. C., Vijayakumar, L. and Raveendra, H. R. 2019. Characterisation of new germplasm accessions for yield and yield related traits in Foxtail millet [Setaria italica (L.) P. Beauv]. Journal of Pharmacognosy and Phytochemistry, SP1: 649-652

Panse, V. G. and Suktme P.V.1969. Statistical methods of agricultural workers $2^{\text {nd }}$ edn. 
Pp. 381, ICAR, Publication, New Delhi. Robinson, H. F. Comstock, R. E. and Harvey, P. H. 1949. Estimates of heritability and the degree of dominance in Corn. Agron. J., 41: 353-359.

Singamsetti, A., Patro, T. S. S. K., Anuradha, N and Divya, M. 2018. Studies on Genetic Variability for Yield and Yield Attributing Traits in Finger millet (Eluesine coracana L. Gaertn). International Journal of Current Microbiology and Applied Sciences, 7, 90-95.
Sivasubramanian, S., and Menon, M. 1973. Heterosis and inbreeding depression in rice. Madras Agric. J., 60: 1139.

Tadele, Z. 2018. Drought Adaptation in Millets In: Abiotic and Biotic Stress in Plants - Recent Advances and Future Perspectives. 639-662p.

Wallace, J. G., Upadhyaya, H. D., Vetriventhan, M., Buckler, E. S., Hash, C. T. and Ramu, P. 2015.The genetic makeup of a global barnyard millet germplasm collection. The Plant Genome.25:1-39.

\section{How to cite this article:}

Ranjana, A. S. Jeena, Ankit Kumar and Rohit. 2020. Genetic Analysis of Barnyard Millet (Echinochloa frumentacea (Roxb.) Link) Germplasm Collected from Uttarakhand Hills for Morphological Traits. Int.J.Curr.Microbiol.App.Sci. 9(03): 1001-1010. doi: https://doi.org/10.20546/ijcmas.2020.903.118 